\title{
Ropeless Fishing to Prevent Large Whale Entanglements: Ropeless Consortium Report
}

\author{
Hannah J. Myers ${ }^{\mathrm{a}, \mathrm{b}}$, Michael J. Moore ${ }^{\mathrm{a}}$, Mark F. Baumgartner ${ }^{\mathrm{a}}$, Sean W. Brillant ${ }^{\mathrm{c}}$, Steven K. \\ Katona $^{\mathrm{d}}$, Amy R. Knowlton ${ }^{\mathrm{e}}$, Lyne Morissette ${ }^{\mathrm{f}}$, Heather M. Pettis ${ }^{\mathrm{e}}$, Geoff Shester ${ }^{\mathrm{g}}$, Timothy B. \\ Werner $^{\mathrm{e}}$
}

${ }^{\mathrm{a}}$ Woods Hole Oceanographic Institution, ${ }^{\mathrm{b}}$ International Fund for Animal Welfare, ${ }^{\mathrm{c}}$ Canadian Wildlife Federation, Dalhousie University - Department of Oceanography, ${ }^{\mathrm{d}}$ College of the Atlantic, ${ }^{\mathrm{e}} \mathrm{New}$ England Aquarium, ${ }^{\mathrm{f}} \mathrm{M}$ - Expertise Marine, ${ }^{\mathrm{g}}$ Oceana

\begin{abstract}
The 2017 North Atlantic right whale (NARW) unusual mortality event and an increase in humpback whale entanglements off the U.S. West Coast have driven significant interest in ropeless trap/pot fishing. Removing the vertical buoy lines used to mark traps on the sea floor and haul them up would dramatically reduce or eliminate entanglements, the leading cause of NARW mortality, while potentially allowing fishermen to harvest in areas that would otherwise need to be closed to protect whales. At the first annual Ropeless Consortium meeting, researchers, fishing industry representatives, manufacturers, conservationists, and regulators discussed existing and developing technological replacements for the marking and retrieval functions of buoy lines. Fishermen and NGO partners shared their experience demonstrating ropeless systems and provided feedback to improve the designs. U.S. and Canadian federal regulators discussed prospects to use ropeless fishing gear in areas closed to fishing with vertical lines, as well as other options to reduce entanglements, and a Massachusetts official shared additional regulatory considerations involved in ropeless fishing in state waters. Sustainable seafood experts discussed consumer market advantages and endangered, threatened, and protected species impacts in sustainability standards and certifications. Moving forward, there is an immediate need to (1) work with industry partners to iteratively test and improve ropeless retrieval and marking systems to adapt them to the specific conditions of the relevant trap/pot fisheries, (2) create data sharing and communications protocols for ropeless gear location marking, and (3) develop regulatory procedures and enforcement capacity to allow legal ropeless gear use.
\end{abstract}

\section{Keywords}

ropeless fishing, bycatch, entanglement, large whales

\section{Introduction}

The top threat to the critically endangered North Atlantic right whale (NARW) is entanglement in vertical lines used in trap/pot fishing gear. Over the last ten years, the number of serious injuries and mortalities from entanglements has increased dramatically, and from 2010 to 2015 entanglement accounted for 85 percent of diagnosed NARW serious injuries and mortalities [12], [28]. On average, a quarter of the population - which presently is estimated at just 411 animals [22], [25] - bears evidence of new entanglement interaction each year [9]. Since the population includes fewer than an estimated 100 reproductive-aged females [25], the death of a single animal from any cause poses a threat to the continued existence of the species. The stress and 
energetic demands of entanglement are also likely contributing to declining calving rates [27]. In 2017, the NARW population experienced an unusual mortality event, in which 17 animalsabout four percent of the population - were observed dead, four of which were confirmed to be caused by entanglement [21], [24], [26]. Three more NARWs were observed dead in 2018, all apparently due to entanglement [21], [26].

Sometimes an entangled NARW can free itself, though the struggle leaves telltale scars. In other instances, the whale's thrashing and rolling causes fishing lines, rope and often associated traps and buoys to wrap ever more tightly around its head, mouth, flippers, and/or tail (Figure 1). Trailing gear can snag other lines and buoys, compounding the problem. In a severe case, the whale may tire and drown relatively quickly, but the process is usually much more drawn out as the entangling rope and gear impede basic movement, feeding, and reproduction, cause chronic infection and damage to muscle and bone, and ultimately weaken the whale until death occurs. An entangled NARW can take an average of six months to die, and the pain and debilitation they endure is a serious animal welfare concern [15], [16].

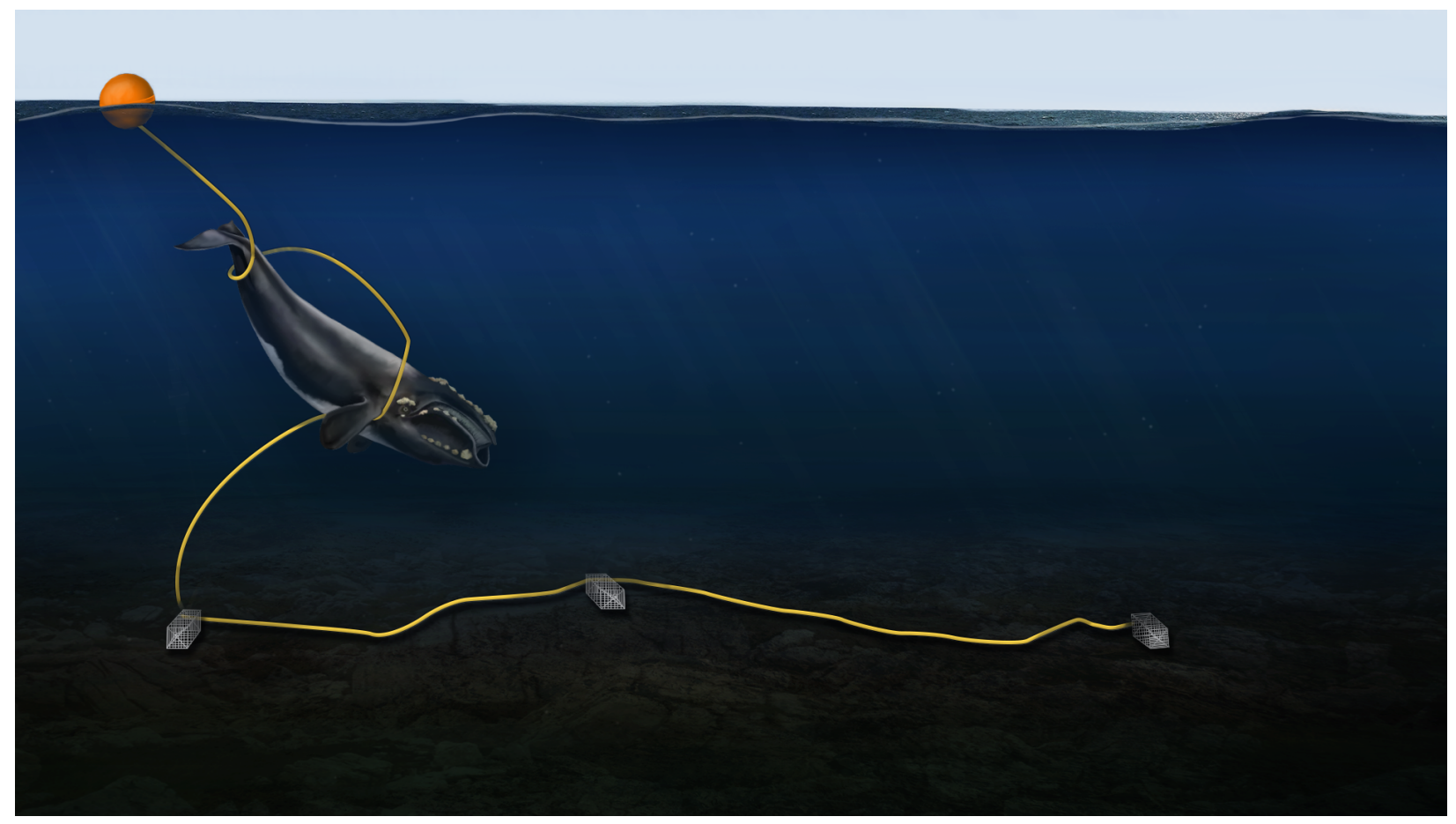

Figure 1: Illustration of a North Atlantic right whale entangled in the vertical line used to connect a buoy at the surface with a string of traps, referred to as a trawl, on the ocean floor. Whales risk mouth and appendage entanglements when swimming through these vertical buoy lines. Credit: Natalie Renier, Woods Hole Oceanographic Institution

The United States is legally bound to protect the NARW under the Endangered Species Act (ESA) and Marine Mammal Protection Act (MMPA), and Canada is required to do so under the Species at Risk Act (SARA). The U.S. National Marine Fisheries Service (NMFS) has set Potential Biological Removal (PBR, the number of animals that can be removed annually from a stock while allowing the population to maintain sustainable growth) at less than one (0.9) [8]. In their most recent Section 7 consultation on the American Lobster Fishery, however, NMFS 
stated that the U.S. lobster trap/pot fishery alone is likely to kill or seriously injure 3.25 whales each year [19].

Since 1997, NMFS has implemented a number of measures designed to identify and reduce NARW entanglements, including gear marking requirements, weak links at the surface, sinking groundlines, trap limits, minimum numbers of traps per vertical line, and a seasonal fishery closure [7]. However, the rate of serious injury and mortality from entanglement has increased dramatically over the same period [7] as the NARW population has taken a downward turn [22] (Figure 2). Though a number of confounding factors have likely contributed to the increasing entanglement mortality rate, including changes in NARW distribution and increased fishing rope strength [10], protective measures to date have been insufficient. Therefore, NMFS and the Atlantic Large Whale Take Reduction Team are considering additional measures to protect NARWs, such as expanded time-area closures, use of reduced breaking strength ropes, and ropeless fishing (defined as gear that does not use vertical buoy lines prior to gear retrieval; Figure 3).

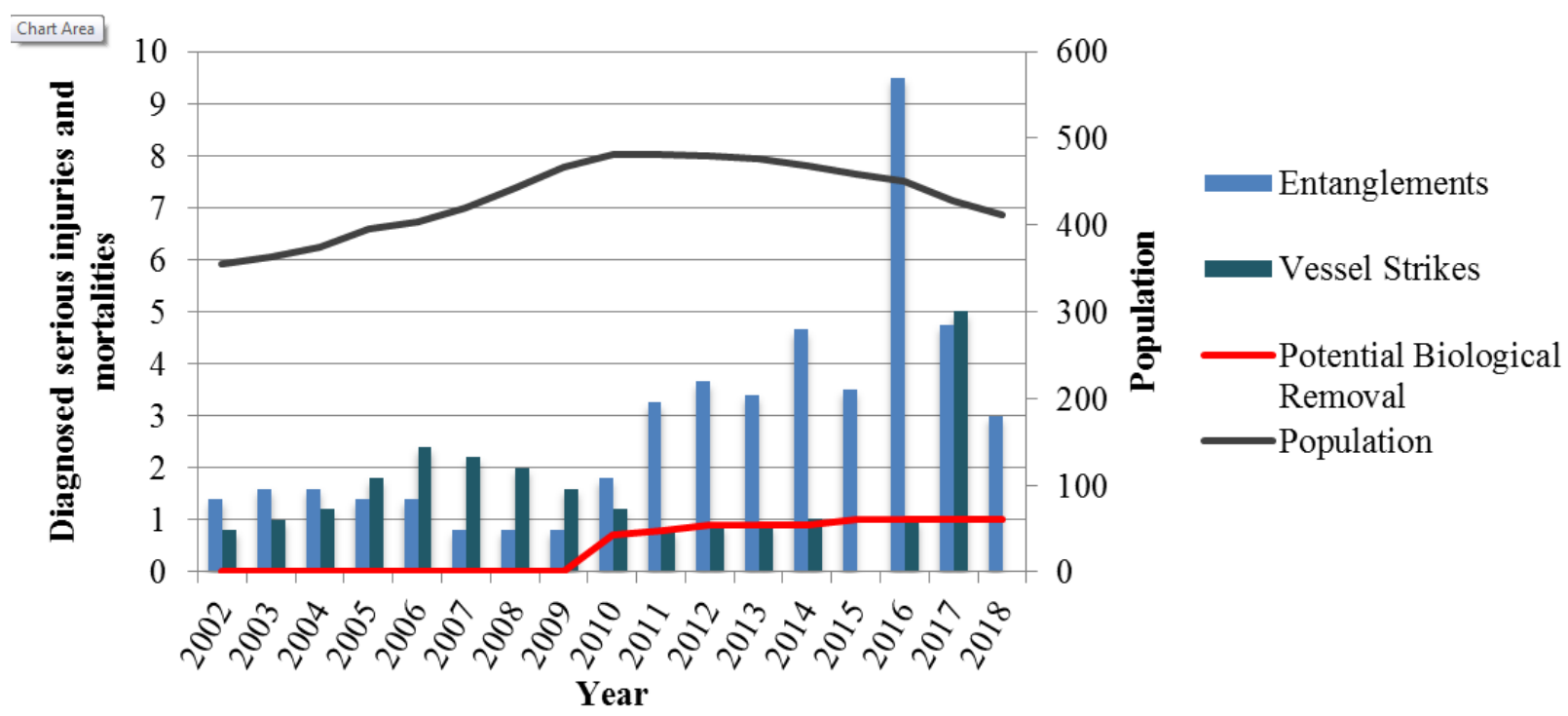

Figure 2: The number of diagnosed serious injuries and mortalities caused by entanglements has increased substantially as the North Atlantic right whale population has taken a downward turn. Potential Biological Removal is set by the National Marine Fisheries Service (NMFS) and represents the number of animals that can be removed annually from a stock while allowing the population to maintain sustainable growth. Source: Pace et al., 2017, North Atlantic Right Whale Consortium Annual Report Cards, NMFS Stock Assessments and preliminary data

Following the unusual mortality event of 2017, when 12 NARWs died in the Gulf of St. Lawrence, the Department of Fisheries and Oceans Canada (DFO) implemented static and dynamic fisheries closures, increased reporting requirements for fishing activity and lost gear, and required limited gear modifications in areas where whales had been observed aggregating [5]. However, in 2018 two NARWs were observed entangled in the Gulf of St. Lawrence and a third was observed entangled in the Bay of Fundy that had last been sighted without gear in the Gulf of St. Lawrence [25]. A fourth whale suffered severe entanglement injuries in the Gulf [25]. 
Three additional NARWs have died in 2018 from entanglement, one of which was traced back to a 2017 entanglement in snow crab gear [21], [26]. The source of entangling gear for the remaining two whales is unknown.

The most recent scientific data from acoustic monitoring and sightings shows that NARWs utilize more of their migratory range throughout the year than previously thought and can be found in areas likely to overlap with trap/pot fisheries throughout the year [4]. Although the evidence is incomplete, recent changes in prey distribution, perhaps associated with changing climate and oceanographic conditions, may influence some of those movements, taking NARW to locations where entanglements had not previously been frequent. Rope taken off of entangled whales has been tracked to trap/pot fisheries throughout the NARW's range [7]. One very promising option to eliminate the threat of entanglement of critically endangered North Atlantic right whales and other protected marine species while allowing the continued operation of fixed gear fisheries is to transition these fisheries to ropeless systems.

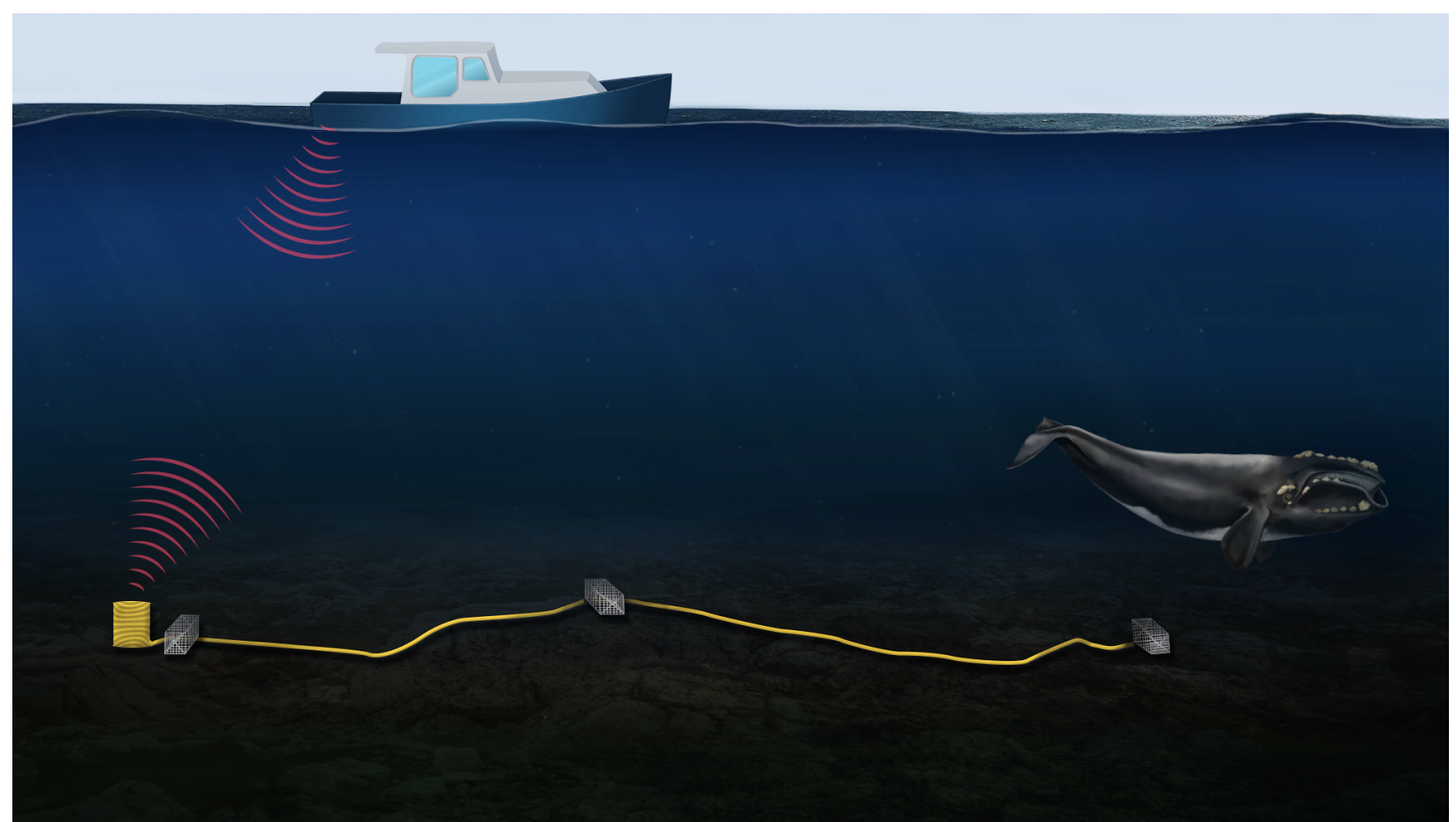

Figure 3: Illustration of ropeless (vertical line-free) fishing gear. Upon receiving an acoustic trigger, a buoy and endline attached to a trap at the end of a trawl deploys for retrieval or a lift bag inflates and brings the attached trap to the surface. Endlines are only used during gear retrieval, or not at all if a lift bag is used. A virtual trap marker visible on a screen in the vessel would replace the marker buoy. Credit: Natalie Renier, Woods Hole Oceanographic Institution

Large whale entanglements on the West Coast of the U.S., particularly of the California/Oregon/Washington humpback whale population, have also increased dramatically over the last five years [3]. Gear from the Dungeness crab trap/pot fishery has been most commonly identified [3]. This commercial and recreational fishery occurs from central California to Alaska and uses a single trap per vertical line. According to the most recent stock assessment, estimated annual mortality and serious injury in the California/Oregon/Washington 
humpback whale population equals 18.8 animals, which exceeds the Potential Biological Removal allocation for U.S. waters of 16.7 animals [3].

The California Dungeness Crab Fishing Gear Working Group, comprised of federal and state agency staff (including members of NMFS and the California Department of Fish and Wildlife), fishermen, conservation NGOs, scientists, and disentanglement teams, is developing a Risk Assessment and Mitigation Program to identify times and places with elevated entanglement risk based on fishing effort, wildlife concentrations, forage conditions, and entanglement reports. In 2018, the California legislature passed a new law (Senate Bill 1309) that gave the California Department of Fish and Wildlife Director new authority to implement time-area closures in the commercial Dungeness crab fishery to prevent wildlife entanglements. Some California fishermen are interested in exploring and testing ropeless fishing gear to reduce entanglement risk, minimize gear loss, and continue fishing in areas that could be closed to traditional fishing methods to protect whales.

The current pace of ropeless gear development and implementation is not commensurate with the urgency of the NARW entanglement mortality crisis and the growing need to address wildlife entanglements in fixed gear globally. However, a number of promising avenues exist to accelerate this process. Researchers, fishing industry representatives, government officials, gear manufacturers, and NGOs discussed the current state of ropeless fishing and options to move forward at the first annual Ropeless Consortium meeting on November $6^{\text {th }}, 2018$ at the New Bedford Whaling Museum in New Bedford, Massachusetts.

The Ropeless Consortium developed out of a workshop entitled "Overcoming Development, Regulatory, and Funding Challenges for Ropeless Fishing to Reduce Whale Entanglement in the U.S. and Canada," held in February 2018 at the Woods Hole Oceanographic Institution, Woods Hole, Massachusetts [2]. The workshop was attended by nearly 100 engineers, manufacturers, fishermen, scientists, conservationists, and regulators from the U.S. and Canada. Its objectives were to (1) discuss the need for and approaches to implementing ropeless fishing to reduce entanglements of large whales in trap/pot fisheries, (2) discuss how to develop regulatory pathways to make ropless fishing legal in the U.S. and Canada, and (3) discuss strategies to fund two phases of development: demonstration/evaluation and experimental fisheries. The Ropeless Consortium was conceived to facilitate information transfer among stakeholders during an annual meeting, thereby accelerating the development and adoption of ropeless fishing to prevent large whale entanglements. This paper reports on the first of these annual meetings. The agenda and list of speakers from the meeting can be found in the Appendix. More information and presentations can be found at www.ropeless.org.

\section{Ropeless retrieval and marking systems}

At the Ropeless Consortium meeting, researchers and gear manufacturers discussed a variety of ropeless technological replacements for the marking and retrieval functions of buoy lines, including GPS and acoustic marking systems and six different lift bag and bottom-stowed rope retrieval designs. Grappling was also discussed as a ropeless retrieval option. Baumgartner et al. [1] have recently summarized these options. 


\subsection{Ropeless location marking options}

Ropeless trap/pot fishing gear must replace the two main functions served by the buoy and endline: marking the location of the gear at the surface and allowing it to be retrieved from the seafloor. Identifying gear location is of particular concern to fishermen. Spatial concentration of traps, especially in some areas of the American lobster fishery, can be very high, and without clear gear location information fishermen are at risk of having their trawls set over inadvertently by another fisherman's gear or towed through by mobile gear (such as trawlers or scallopers). These layovers can lead to difficulty retrieving trawls, damage to gear, or gear loss. Fouling mobile gear with traps is also a major loss of time and fishing efficiency for mobile gear operators. Federal and state regulations also require the buoy system to identify fishermen's gear and enforcement agencies regularly haul up trawls to inspect compliance with gear regulations. Ropeless fishing inherently lacks a visual surface marker, so a new trap marking system to prevent gear conflicts and allow regulators to manage traps in the water must be developed.

There are two options to replace the gear location marking function: GPS and acoustic marking. First, fishermen can use GPS systems to mark the location of their gear. When a fisherman sets a trawl, they can mark its location on the GPS plotter they already use or with apps available or in development with ropeless gear companies. Desert Star Systems LLC provides a free Android app called Ropeless Fisher to do this, and other ropeless gear companies including EdgeTech and Ashored Innovations are also developing GPS-based gear marking apps. In practice, many fishermen already often mark the location of their gear on their GPS plotters so that it is easier to find when they return to harvest their catch. GPS marking systems have minimal upfront costs and, in many cases, fishermen may already have the necessary technology.

However, ropeless GPS marking systems must also share gear location with local fixed and mobile gear fishermen and regulators. Some fishermen have expressed a desire not to share their gear location beyond the immediate vicinity needed to avoid gear conflicts. Some GPS marking systems, such as the Desert Star Ropeless Fisher app, accommodate this by allowing the gear owner to specify a range - such as 0.5 miles - within which the gear can be visible to others. Gear locations can be uploaded to public maps available to both fixed and mobile fishermen in the area when they are within cell phone range or if they connect instantaneously through onboard satellite communication technology. For those lobster and snow crab fishing vessels not already equipped for satellite communication, upgrading can be a low-cost technology (for example, the Garmin inReach Iridium puck is one commercial option). However, GPS marking is unhelpful if gear has moved, such as in a storm or mobile gear interaction, since the deployment location will no longer match the actual location of the gear. Furthermore, a surface GPS position record does not account for any tide- or current-induced horizontal drift of the gear during its descent to the bottom.

Acoustic modem-based location systems offer an alternative marking option. Acoustic modems could remotely report information on trawl location and encrypted registration information to fishermen and regulators at the surface. Acoustic modems allow data to be passed through water via acoustic waves, and have been used in oceanographic, industrial, and military applications to allow devices to communicate with one another from the seafloor, the water column, and the surface. Modems on a trap or at the ends of a trawl can report the real-time location of the trawl (as public data) as well as owner registration and permit information (as encrypted, private data 
available only to the owner, enforcement officials, and regulators) when the modem is interrogated by a hull-mounted modem on a passing ship. Real-time trawl locations can then be immediately displayed on fixed and mobile gear fishermen's chart plotters to aid in avoiding gear conflicts.

This system ensures that gear location is only reported to vessels within the trap modem's vicinity; just as with the buoy-marking system that is currently used, fishermen or regulators would have to be on site to see where gear is located on the sea floor. Acoustic modems can pair with GPS systems onboard passing vessels to enable the trawl modems to self-locate, and if a passing vessel detects a trawl that has moved (such as in a storm) it can automatically report its new location to the owner through technology as simple as a text message. Acoustic gear location marking could thereby significantly reduce lost gear, which is a considerable cost to the trap/pot fishing industry and a substantial contributor to marine debris and ghost fishing. A 2012 study by the Massachusetts Division of Marine Fisheries found that the annual value of lost traps and the resultant reduced yield in lobsters represents $\$ 252,000$ to $\$ 665,000$ (USD) in lost revenue to the lobster fishery in Cape Cod Bay alone [13]. In another study of the Massachusetts lobster fishery, 8.5 percent of buoy lines parted within one fishing season [11]. While acoustic locating technologies are a promising option, they may be expensive, at least initially.

Acoustic modems are already commercially available for other purposes, but they must be adapted to work in trap/pot fishing operations. This includes: (1) incorporating a mechanism to trigger retrieval upon acoustic command, where applicable; (2) developing self-localization capabilities; and (3) setting up communication and data protocols to ensure interoperability among modem and wheelhouse display manufacturers.

\subsection{Ropeless retrieval options}

There are three main approaches to ropeless gear retrieval: (1) grappling; (2) bottom-stowed rope bags, traps/cages, or spools that release a buoy and endline to the surface upon receiving an acoustic trigger; and (3) inflatable (i.e. salvage) bags that fill with air and come to the surface with the trap or pot upon receiving an acoustic trigger.

Grappling, in which fishermen use a modified hook to catch the groundline between traps, is commonly used to retrieve trawls when buoy lines are lost. This is common for fisheries that share areas with high levels of ocean traffic, such as in Boston Harbor, Massachusetts, U.S. and St. John Harbor, New Brunswick, Canada. Fishermen in Boston Harbor typically use weak endlines so as to avoid equipment damage from ship, tugs, and barges that could tow a trawl if the endline is too strong, and often lose buoys and endlines when they are fouled by a propeller or the weak rope separates in rough conditions [17]. In the relatively shallow (less than 50 feet deep) waters of Boston Harbor, traps that have lost buoy markers can be grappled relatively easily even if other gear has been laid over them in the buoy's absence.

Grappling is also used in the golden crab fishery located off the east coast of Florida, where the strong currents of the Gulf Stream would exert too much drag on endlines and pull the surface buoys under. Fishermen in the golden crab fishery routinely grapple for trawls containing 35 to 50 traps in waters 1000 to 2000 feet deep, but rarely experience gear conflicts because the fishery is relatively small and permit holders fish by zone [17]. Grappling is also occasionally 
used illegally in the American lobster fishery by fishermen as a way to exceed their trap limits, and Marine Patrol Officers have previously located and retrieved trawls that were not marked with a buoy [17].

Grappling involves little or no upfront cost for most fishermen, and significantly reduces rope costs by eliminating the need for vertical lines. Grappling retrieval time is likely to vary significantly with individual skill and ocean conditions; however, for many fishermen the time taken to retrieve trawls by grappling is significantly longer than hauling endlines and could reduce the number of traps hauled per day and daily landings. In a study by the Maine-based Pemaquid Fishermen's Coop, retrieving trawls by grappling took on average 14.2 minutes, while retrieving traps with the standard endline and pot hauler took one minute [23]. The potential for damage to equipment and reduced human safety associated with dragging a grapple along the sea floor are also important considerations, and grappling may not be an option in the snow crab fisheries where individual pots are very heavy and pots are typically fished as singles, not trawls.

Other designs for retrieving ropeless pot/trap gear (i.e. bottom-stowed rope and inflatable bags) require the use of acoustic releases. Acoustic release systems offer a more accurate and rapid, though initially more expensive, alternative to grappling. Economics of scale could also lead to significant price reductions if demand in trap/pot fisheries drove high levels of production. Any of these methods could also reduce the incidence of lost gear and ghost fishing. At the 2018 Ropeless Consortium meeting, several designers, manufacturers, and companies presented their ropeless retrieval systems, which are summarized in Table 1.

\begin{tabular}{|c|c|c|}
\hline Manufacturer & Gear Type & Previous demonstrations and use \\
\hline $\begin{array}{l}\text { Desert Star Systems } \\
\underline{\text { LLC }}\end{array}$ & $\begin{array}{l}\text { Bottom-stowed } \\
\text { rope bag }\end{array}$ & $\begin{array}{l}\text { Used by the Australian rock lobster fishery off New South Wales } \\
\text { since 2013; demonstrated by Massachusetts Lobstermen's } \\
\text { Association, California Dungeness crab fishery, Coldwater Lobster } \\
\text { Association, and Acadian Crabber's Association in } 2018\end{array}$ \\
\hline EdgeTech & $\begin{array}{l}\text { Bottom-stowed } \\
\text { rope cage }\end{array}$ & At-sea engineering trials \\
\hline Fiomarine & $\begin{array}{l}\text { Bottom-stowed } \\
\text { rope spool }\end{array}$ & $\begin{array}{l}\text { Used by the Australian and U.S. Navies, in the oil and gas industry, } \\
\text { and in oceanographic research and data collection for over } 20 \text { years; } \\
\text { demonstrated in the California Dungeness crab fishery in } 2018\end{array}$ \\
\hline SMELTS & Lift bag & Engineering trials in Cape Cod Bay and Stellwagen Bank \\
\hline Ashored Innovations & $\begin{array}{l}\text { Bottom-stowed } \\
\text { rope cage }\end{array}$ & Demonstrated with the Coldwater Lobster Association \\
\hline $\begin{array}{l}\frac{\text { Woods Hole }}{\text { Oceanographic }} \\
\text { Institution }\end{array}$ & $\begin{array}{l}\text { Bottom-stowed } \\
\text { rope spool } \\
\text { (designed for } \\
\text { offshore) }\end{array}$ & Engineering trials at dock \\
\hline Grappling & & $\begin{array}{l}\text { Frequently used in commercial fishing to recover lost gear when } \\
\text { buoy lines separate and used illegally to exceed trap limits }\end{array}$ \\
\hline
\end{tabular}

Table 1: Ropeless retrieval systems in development or use in U.S. and Canadian trap/pot fisheries

Desert Star Systems LLC, from California, sells two acoustic release designs that have been used in the ropeless rock lobster fishery off New South Wales, Australia since 2013. Upon receiving 
an acoustic signal from a transducer aboard the gear owner's vessel, the retrieval unit releases a buoy and an endline that is stored in a bag attached to the top of the trap. This bottom-stowed rope bag system is compatible with standard fishing gear, such as winches and line haulers, currently used to bring the trawls on board, so fishermen can retrieve the buoy and haul the gear as if it were a traditional surface buoy and endline. In 2018, fishermen with the Coldwater Lobster Association of Nova Scotia, the Acadian Crabber's Association in the southern Gulf of St. Lawrence, the Massachusetts Lobstermen's Association with NGO partner the International Fund for Animal Welfare, and the California Dungeness crab fishery with NGO partner Oceana demonstrated use of Desert Star retrieval units and GPS marking app Ropeless Fisher.

The Massachusetts-based underwater technology company EdgeTech has created a ropeless retrieval system currently in production. In the EdgeTech system, an acoustic release and coiled rope are contained in a release cage designed with the same materials and dimensions as a lobster trap. Buoys are attached to the rope and top cover of the release cage, and when the device receives an acoustic release signal the top cover detaches and floats to the surface for hauling. The release system uses replaceable 9-volt batteries that will last for one year and is designed with a nickel-aluminum-bronze alloy to be resistant to corrosion. Company engineers estimate that it will last 10 to 20 years.

Fiomarine Industries, based in Australia, similarly offers a ropeless retrieval system with an acoustically triggered bottom-stowed endline and buoy, called the Fiobuoy. This design differs from the previous in that the bottom-stowed rope is stored on a spool instead of in a bag or cage. The Fiomarine retrieval system is commercially available and has been used by the Australian and U.S. Navies (for example, for mine recovery), in the oil and gas industry for retrieving equipment from the seafloor, and in oceanographic research and data collection for over 20 years. Fiomarine's system also includes a programmed automatic release (i.e. with a specified date and time), which can be entered as a back-up in case the acoustic release does not deploy. The spool can be recoiled with a motorized or hand winder for quick redeployment as the trap is hauled to the surface. Fishermen in the California Dungeness crab fishery and the NGO Oceana partnered to demonstrate the Fiomarine system in 2018 and have additional trials planned for 2019. Fiomarine has addressed the management of ropeless gear deployments through an integrated database for fishers and regulators, and is currently working on system modifications to better integrate into the Dungeness crab fishery based on fishermen's suggestions and feedback thus far.

Engineers with the Woods Hole Oceanographic Institution (WHOI) in Massachusetts have also developed a bottom-stowed spooled rope retrieval system specifically designed for deep-water fishing operations off the continental shelf, where there are strong currents and water depths that range from 100 to 300 meters deep. Ropeless fishing gear in these conditions needs to be functional in a wide range of depths. Therefore, the WHOI system involves a line spool on a cartridge with a foam core, since line bags filled with 500 to 900 meters of rope are more likely to snag. In order to enable a quicker at-sea gear turnaround time, when a trawl is retrieved fishermen can swap out the line cartridge for a previously prepared spool, while recovered line is stored in the ship's hold or in plastic drums on the deck for re-spooling on land. The WHOI system is compatible with standard offshore fishing gear, such as line, floats, trawl anchors, and pot haulers, and includes rechargeable batteries. It uses a WHOI acoustic modem, a mature 
acoustic communications system that has been used in commercial and military applications for nearly 20 years. The ropeless system has been dock tested, with at-sea trials in deep water planned for 2019 .

The non-profit Sea Mammal Education Learning Technology Society (SMELTS), located in Washington state, has developed a lift bag retrieval system that is remotely operated using a WHOI acoustic modem. The SMELTS lift bag does not employ any vertical line; instead, an acoustic modem, release electronics, and compressed air cylinder are contained within a standard lobster trap. When the release system receives an acoustic signal, the compressed air cylinder fills the lift bag on top of the trap with air to bring the trap and groundline attaching the lift trap to the rest of the trawl to the surface. Depending on the depth fished and the volume of the air cylinder, SMELTS estimates that the system can deploy six to 50 times without replacing the air cylinder. The SMELTS lift bag system has gone through engineering trials in Cape Cod Bay and Stellwagen Bank and will be used in commercial fishing tests in Massachusetts and the southern Gulf of St. Lawrence during 2019.

Finally, the ropeless retrieval system in development with Nova Scotia-based Ashored Innovations was in the patent process at the time of the Ropeless Consortium meeting, so limited information was available on its design. However, in January 2019 Ashored Innovations successfully filed a provisional patent and has since shared further information on their system. It uses a bottom-stowed coiled rope cage and release mechanism consisting of a t-bar and drive shaft. When the device is acoustically triggered, the top of the cage is released and comes to the surface with the attached buoy and rope. The current model has been deployed with a programmed time release, with acoustic release in development that has the potential to gather information on sea conditions to improve fishing efficiency. Ashored Innovations is also developing capacity to communicate location information via text using Iridium satellite communications. The Ashored system has been demonstrated with the Coldwater Lobster Association off the southwest coast of Nova Scotia.

\section{Ropeless fishing regulations}

At the Ropeless Consortium meeting, officials from NMFS's Greater Atlantic Regional Fisheries Office and DFO discussed prospects to use ropeless fishing gear in areas that are or could become closed to fishing with vertical lines, as well as other options to reduce the threat of entanglement to NARW and other species. A representative of the Massachusetts Division of Marine Fisheries shared additional regulatory considerations involved in ropeless fishing in state waters.

Interest in ropeless fishing in both Canada and the U.S. has been driven in large part by the potential for fishermen to access important fishing grounds that overlap with NARW habitat areas that either currently are or could become closed to trap/pot fishing with vertical lines. In 2018, DFO implemented a system of static and dynamic management areas in the southern Gulf of St. Lawrence based on their best knowledge of NARW aggregations in both 2017 and 2018. Although fishermen in these areas still met snow crab quotas and continued to fish lobster, there were costs associated with gear removal and fishing in different areas prompted by time-area closures, and some fishermen and associated industries were more affected than others. Demand for ropeless fishing has increased because fishermen want to continue to harvest in these areas 
without exposing NARWs to risk of entanglement. Although 2019 fisheries management measures have not yet been announced, NARW arrival and residency times in the Gulf of St. Lawrence in 2018 were comparable to 2017 [6], and DFO officials have signaled that continued protective regulations in this area remain a high priority.

DFO and other Canadian federal and provincial agencies have provided significant support for ropeless gear testing. The Atlantic Fisheries Fund and the Province of New Brunswick are supporting 15 subprojects over three years with the Acadian Crabber's Association, Association des Pêcheurs Professionnels Crabiers Acadiens, and Crabiers du Nord-Est, including tests of Desert Star, Edgetech, and SMELTS retrieval systems and development of ropeless gear tracking technologies. The Atlantic Fisheries Fund and the Province of Nova Scotia have jointly funded the Coldwater Lobster Association to test Desert Star gear. DFO has also provided financial support to the Grand Manan Fishermen's Association to test Desert Star gear and to Ashored Innovations to develop and test newly designed ropeless gear.

At present, the Canadian Fisheries General Regulations (s27) [14] require trap/pot fishing gear to be identified through a surface buoy system. Ropeless fishing would violate that regulation. DFO has shown willingness to provide experimental fishing licenses for fishermen interested in testing ropeless gear and a desire to continue supporting additional ropeless fishing tests in 2019. Canadian fishing regulations are implemented as conditions on licenses; therefore, ropeless fishing could potentially advance as a condition that certain licenses could only be fished without the use of a buoy and endline.

Similarly, fishermen affected by the seasonal closures in the Massachusetts Restricted Area (Cape Cod and Massachusetts Bays) and the Great South Channel have repeatedly requested access to fishing in these areas during closure periods. Ropeless fishing may provide an opportunity for them to do so. In 2010, NMFS did not allow ropeless fishing in the Great South Channel closure area despite consensus by the advisory Atlantic Large Whale Take Reduction Team. However, on September 28 ${ }^{\text {th }}$, 2018, NMFS published an Advance Notice of Proposed Rulemaking to modify the Massachusetts Trap/Pot Restricted Area and the Great South Channel Trap/Pot Restricted Area to allow ropeless fishing [20].

This proposed rule would change the definition of these particular closed areas under the Marine Mammal Protection Act to prohibit trap/pot fishing with a vertical line, instead of all trap/pot fishing [20]. However, fishermen interested in fishing ropeless in the closures would need to apply for and receive an Exempted Fishing Permit (EFP, allowed for under the Magnuson Act) from NMFS to receive an exemption from surface-system marking requirements. Since only fishermen who receive an approved EFP (which often contain research or data collection conditions) would be allowed to fish in closed areas, NMFS could closely monitor this initial experiment in commercial ropeless fishing. Allowing commercial ropeless fishing in the closed areas would offer an important economic incentive for fishermen to test different ropeless retrieval and marking systems in actual fishing conditions, an important step in the cooperative, iterative development and adoption of ropeless fishing gear.

EFPs can also be allotted for ropeless fishing outside of current closure areas, though conflicts with mobile fishing gear, such as scallop dredgers, remain a top concern for trap/pot fisheries 
that want to use ropeless systems. NMFS has compiled a map of areas currently closed to mobile gear either year-round or for part of the year for habitat protection or to prevent gear conflicts, available at www.greateratlantic.fisheries.noaa.gov/ropeless. In addition to testing in presently closed areas where the incentive is high and informal agreements could be made with mobile fishermen, these areas outside of closed areas but with no mobile gear fishing allowed are also strong options to begin experimenting with ropeless gear. NMFS also has a Gear Research Group that provides research expertise and some funding for fishermen involved in gear testing, and has solicited interest from fishermen to test ropeless gear.

In the U.S., additional regulations will be needed to allow ropeless fishing in state waters. For example, the Massachusetts Division of Marine Fisheries (DMF) requires the use of vertical lines and surface systems for trap/pot fishing in state waters (as do other states). However, because this is a state regulation, not a state statute, DMF can provide a Letter of Authorization for a set period of time to allow gear experimentation in state waters, and did so in July 2018 to allow a member of the Massachusetts Lobstermen's Association and the International Fund for Animal Welfare to demonstrate the Desert Star ropeless system. Fishermen who operate with a federal permit would need to receive an EFP for ropeless gear use from NMFS as well. In certain states, finding areas where mobile and fixed gear do not both occur can be very difficult. The Northeast Data Portal contains information on commercial fishing activity tracked using Vessel Monitoring System (VMS) data; trap/pot fishermen could use this data to identify potential areas to test ropeless systems where the likelihood of co-occurrence with mobile gear is low.

Significant concerns about ropeless gear enforcement have been expressed in both the U.S. and Canada. Officials responsible for checking gear compliance need to have the ability to haul gear to evaluate whether traps meet escape panel requirements, legal bait is being used, weak links and sinking groundline are being used, etc. Similarly, trap limits are typically enforced with individual trap tags in both countries, and enforcement must be able to document these tags. Enforcement officials must have the capacity to retrieve and deploy ropeless gear. Moreover, developing a ropeless locating system would also likely require regulatory management of an acoustic- and GPS-compatible location data sharing system.

\section{Developing a consumer market advantage}

At the Ropeless Consortium meeting, representatives of the Marine Stewardship Council and the New England Aquarium's Fisheries and Aquaculture Solutions Program at the Anderson Cabot Center for Ocean Life discussed using consumer market advantages, such as environmental evaluations of fisheries, to reduce the ecosystem impacts of fishing. These evaluations include scoring of bycatch and endangered, threatened, and protected species impacts in sustainability criteria and traceability in sustainable seafood markets, among other factors. Moore [18] has also recently described how consumer demand can encourage reduced cetacean bycatch in trap/pot fisheries.

Developing a consumer market advantage for lobster, crab, and other trap/pot fishing products caught using ropeless gear could offer an economic incentive to support fishermen in transitioning to and operating ropeless gear. Although the sustainability of the target stock is a key consideration in sustainable seafood certifications, growing awareness of the impacts on non-target species and surrounding ecosystems has encouraged some certification groups to 
update some of their requirements, particularly around endangered, threatened, and protected species bycatch.

A significant portion of the seafood sold in the North American and European markets comes from companies that have committed to buying and selling some amount of sustainable seafood. Corporate/NGO partnerships such as those that are a part of the Conservation Alliance for Seafood Solutions and the Seafood Alliance support companies in identifying and purchasing sustainable products. Some companies consider specific factors, such as the health of the target stock, fishery management, the impact of fishing gear on bycatch and habitat, and how those are managed. Others depend on third-party certifiers and NGO ratings and commit to buying a proportion of certified products or products that meet a sustainability rating.

A number of trap/pot and gillnet fisheries in the northwest Atlantic have the potential to put NARW at entanglement risk, including some that are currently certified by the Marine Stewardship Council (MSC) or in full assessment (Table 2). Following the 2017 unusual mortality event, the Gulf of St. Lawrence snow crab fishery's MSC certification was suspended in March 2018 due to the entanglements attributed to the fishery through gear identification. The fishery was recently audited to assess progress, with results expected in March 2019. The Îles de la Madeleine and Gulf of Maine lobster fisheries and three Canadian snow crab fisheries include specific NARW conditions within their MSC certifications. Similarly, the fixed gear sector of the MSC-certified Mid-Atlantic spiny dogfish fishery also has conditions around NARWs, and a herring gillnet fishery in the Gulf of St. Lawrence is currently being evaluated for NARW impacts. This means that over the course of the five-year certificate, these fisheries are required to show progress on documenting their impacts on NARWs, updating management measures for NARWs, reducing risk of serious injuries or mortalities to NARWs or some combination of all these.

\begin{tabular}{|c|c|c|c|}
\hline Fishery Name & Gear & MSC status & Jurisdiction \\
\hline AQIP snow crab (northern GoSL) & Pots/traps & In assessment & Canada \\
\hline AQIP Gulf of St. Lawrence Greenland halibut & $\begin{array}{l}\text { Gillnets, } \\
\text { longlines }\end{array}$ & In assessment & Canada \\
\hline $\begin{array}{l}\text { Bay of Fundy, Scotian Shelf and Southern Gulf of } \\
\text { St. Lawrence lobster }\end{array}$ & Pots/traps & Certified & Canada \\
\hline Canada Atlantic halibut & $\begin{array}{l}\text { Gillnets, } \\
\text { longlines }\end{array}$ & Certified & Canada \\
\hline Canada Scotia Fundy haddock & $\begin{array}{l}\text { Gillnets, } \\
\text { longlines }\end{array}$ & Certified & Canada \\
\hline Eastern Canada offshore lobster & Pots/traps & Certified & Canada \\
\hline Gaspésie lobster & Pots/traps & Certified & Canada \\
\hline Gulf of Maine lobster & Pots/traps & Certified & U.S. \\
\hline Gulf of St. Lawrence fall herring & Gillnets & Certified & Canada \\
\hline Gulf of St. Lawrence snow crab & Pots/traps & Suspended & Canada \\
\hline Îles de la Madeleine lobster & Pots/traps & Certified & Canada \\
\hline Newfoundland and Labrador snow crab & Pots/traps & Certified & Canada \\
\hline Prince Edward Island lobster & Pots/traps & Certified & Canada \\
\hline Scotian Shelf snow crab & Pots/traps & Certified & Canada \\
\hline U.S. Atlantic spiny dogfish & Gillnets & Certified & U.S. \\
\hline
\end{tabular}

Table 2: MSC fisheries that overlap with NARW range. Source: www.msc.org 
The MSC is currently revising their standard in relation to endangered, threatened, and protected species and phasing in a requirement in which the cumulative impacts of certified fisheries on protected species will be assessed collectively, such that the overall impacts of all trap/pot and gillnet fisheries on the NARW population could lead to reconsideration of individual certifications. This requirement is already mandatory for some certified fisheries, like the snow crab fisheries and the Îles de la Madeleine lobster fishery. As more fisheries become re-certified, they will have to consider cumulative impacts from all fisheries adhering to this new requirement.

However, impacts to NARWs from fisheries that are not MSC certified are not included in the MSC cumulative impacts requirement. Some company policies, such as those of Walmart Inc. and the Kroger Co., support purchasing seafood products from fisheries that are not certified or do not meet a sustainability ranking if they are involved in a fishery improvement project. Fishery improvement projects recognized by NGOs in the Conservation Alliance for Seafood Solutions engage different stakeholders, including seafood suppliers, fishing industry, and seafood industry members, among others to address environmental challenges in a fishery. These efforts may provide another market pathway for crab, lobster, and seafood products from fisheries interested in adopting ropeless gear.

\section{Conclusion}

Although ropeless fishing marking, retrieval, and enforcement systems are not currently ready to be used at scale in Atlantic lobster and snow crab fisheries or the West Coast Dungeness crab fishery, interest in ropeless fishing has increased significantly in response to the 2017 NARW unusual mortality event, the growing entanglement risk on both coasts, and increased changes in fisheries management. Ropeless fishing offers a very strong option to eliminate the threat of entanglement to NARWs and other marine species in the long term and the potential ability to continue fishing in closed areas in the short term. There is an urgent need for iterative research and development of ropeless fishing in commercial operations, which can take place immediately by integrating ropeless gear into a legally fished gear system that has endlines and buoys. Further testing of truly ropeless gear (without endlines and buoys) can happen through Exempted Fishing Permits or licenses and/or expanded closures that allow ropeless fishing. The capacity to regulate and enforce ropeless fishing must progress in parallel.

The window for preventing extinction of NARWs is short. Ropeless fishing needs to advance quickly to help avert the existing NARW entanglement crisis and address the immediate need to reduce wildlife entanglements off the U.S. West Coast while keeping the fishing industry viable. Market incentives and opportunities to fish in otherwise closed areas will help to accelerate much-needed development and adoption. Fishing, management, enforcement, conservation, and manufacturing stakeholders all share the goal of establishing economically and ecologically sustainable fisheries while protecting NARWs and other marine wildlife. Their collaboration through the Ropeless Consortium forms a strong foundation for the work needed to achieve that goal. 


\section{Acknowledgments}

We thank speakers at the Ropeless Consortium meeting for their presentations and review of this report.

\section{Works Cited}

[1] Baumgartner, M.F., Werner, T.B., and M.J. Moore. 2019. Urgent Need for Ropeless Fishing: Removing End Lines to Protect Right Whales. Sea Technology Magazine. 60:3, 23-27.

[2] Baumgartner, M.F., Moore, M.J., Kraus, S.D., Knowlton, A.R. and T.B. Werner. 2018. Overcoming Development, Regulatory and Funding Challenges for Ropeless Fishing to Reduce Whale Entanglement in the U.S. and Canada. Workshop Report. Woods Hole, Massachusetts. February 1, 2018. Available at www.ropeless.org.

[3] Carretta, J.V., Forney, K.A., Oleson, E.M., Weller, D.W., Lang, A.R., Baker, J., Muto, M.M., Hanson, B., Orr, A.J., Huber, H., Lowry, M.S., Barlow, J., Moore, J.E., Lynch, D., Carswell, L. and R.L. Brownell, Jr. 2018. U.S. Pacific Draft Marine Mammal Stock Assessments: 2018. NOAA-TM-NMFS-SWFSC-XXX

[4] Davis, G.E., Baumgartner, M. F., Bonnell, J.M., Bell, J., Berchok, C., Bort Thornton, J., Brault, S., Buchanan, G., Charif, R.A., Cholewiak, D., Clark, C.W., Corkeron, P., Delarue, J., Dudzinski, K., Hatch, L., Hildebrand, J., Hodge, L., Klinck, H., Kraus, S., Martin, B., Mellinger, D.K., Moors-Murphy, H., Nieukirk, S., Nowacek, D.P., Parks, S., Read, A.J., Rice, A.N., Risch, D., Širović, A., Soldevilla, M., Stafford, K., Stanistreet, J.E., Summers, E., Todd, S., Warde, A., and S.M. Van Parijs. 2017. Long-term passive acoustic recordings track the changing distribution of North Atlantic right whales (Eubalaena glacialis) from 2004 to 2014. Scientific Reports, 7(1), 13460. doi:10.1038/s41598-017-13359-3

[5] Fisheries and Oceans Canada. 2018. Government of Canada unveils its plan for protecting North Atlantic right whales in 2018. March 28 $8^{\text {th }}, 2018$.

https://www.canada.ca/en/fisheries-oceans/news/2018/03/government-of-canada-unveilsits-plan-for-protecting-north-atlantic-right-whales-in-20180.html

[6] Fisheries and Oceans Canada. 2018. Technical Briefing: North Atlantic Right Whales. December $4^{\text {th }}, 2018$. Montreal, QC.

[7] Hayes, S.A., Gardner, S., Garrison, L.P., Henry, A., and L. Leandro. 2018. North Atlantic Right Whales- Evaluating Their Recovery Challenges in 2018. National Oceanic and Atmospheric Administration Technical Memorandum NMFS-NE-247.

[8] Hayes, S.A., Josephson, E., Maze-Foley, K., Rosel, P.E., Byrd, B., Chavez-Rosales, S., Cole, T.V.N., Engleby, L., Garrison, L.P., Hatch, J., Henry, A., Horstman, S.C., Litz, J., Lyssikatos, M.C., Mullin, K.D., Orphanides, C., Pace, R.M., Palka, D.L., Soldevilla, M., and F.W. Wenzel. 2018. US Atlantic and Gulf of Mexico Marine Mammal Stock Assessments - 2017 (Second Edition). NOAA Technical Memorandum NMFS-NE-245.

[9] Knowlton, A. R., Hamilton, P. K., Marx, M. K., Pettis, H. M., and S.D. Kraus, S. D. 2012. Monitoring North Atlantic right whale (Eubalaena glacialis) entanglement rates: a $30 \mathrm{yr}$ retrospective. Marine Ecology Progress Series, 466, 293-302. doi: 10.3354/meps09923

[10] Knowlton, A.R., Robbins, J., Landry, S., McKenna, H.A., Kraus, S.D., and T.B. Werner. 2016. Implications of fishing rope strength on the severity of large whale entanglements. Conservation Biology. 30:2, 318-328. doi: 10.1111/cobi.12590. 
[11] Knowlton, A.R., Malloy, R., Kraus, S.D., and T.B. Werner. 2018. Development and Evaluation of Reduced Breaking Strength Rope to Reduce Large Whale Entanglement Severity. Report to the Massachusetts Office of Energy and Environmental Affairs.

[12] Kraus S.D., Kenney R.D., Mayo C.A., McLellan W.A., Moore M.J., and D.P. Nowacek. 2016. Recent scientific publications cast doubt on North Atlantic right whale future.

Frontiers in Marine Science, 3:137. doi: 10.3389/fmars.2016.00137

[13] Massachusetts Division of Marine Fisheries. 2012. Impacts of Ghost Fishing to the American Lobster Fishery. Report to the National Fish and Wildlife Foundation, Marine Debris Program. NFWF/Legacy Grant Project ID: 0306.09.018690

[14] Minister of Justice. 2017. Fishery (General) Regulations; Regulations Respecting Fishing and Fish Habitat in General and the Payment of Penalty and Forfeiture Proceeds Under the Fisheries Act. Last amended May 29, 2015. http://laws-lois.justice.gc.ca

[15] Moore, M.J. and J.M. van der Hoop. 2012. The painful side of trap and fixed net fisheries: chronic entanglement of large whales. Journal of Marine Biology. 2012, ID 230653. doi: $10.1155 / 2012 / 230653$

[16] Moore, M.J. 2014. How we all kill whales. ICES Journal of Marine Science, 71:4, 760-763. doi: 10.1093/icesjms/fsu008

[17] Moore, M.J. 2018. Ropeless Fishing in Practice Today. Presentation to the Ropeless Workshop, February $1^{\text {st }}, 2018$, Woods Hole, MA. https://ropeless.org/wpcontent/uploads/sites/112/2018/02/4.-Moore_Current_Ropless.pdf

[18] Moore, M.J. 2019. How we can all stop killing whales: a proposal to avoid whale entanglement in fishing gear. ICES Journal of Marine Science, fsy194. doi: 10.1093/icesjms/fsy194

[19] National Marine Fisheries Service (NMFS), Northeast Region. 2014. Section 7 Consultation on the American Lobster Fishery. NMFS tracking number NER2014-11076.

[20] National Marine Fisheries Service (NMFS). 2018. Advance Notice of Proposed Rulemaking; request for information. Published in the Federal Register September $28^{\text {th }}$, 2018. 50 CFR Part 229, Docket No. 180702603-8603-01.

[21] National Marine Fisheries Service (NMFS), National Oceanic and Atmospheric Administration. 2018. 2017-2018 North Atlantic Right Whale Unusual Mortality Event. https://www.fisheries.noaa.gov/national/marine-life-distress/2017-2018-north-atlanticright-whale-unusual-mortality-event. Last updated November $5^{\text {th }}, 2018$.

[22] Pace, R.M., Corkeron, P.J., and S.D. Kraus. 2017. State-space mark-recapture estimates reveal a recent decline in abundance of North Atlantic right whales. Ecology and Evolution. 7, 8730-8741. doi: 10.1002/ece3.3406

[23] Pemaquid Fishermen's Coop. 2012. Large Whale Entanglement Mitigation Gear Research Projects. Final Report to the National Marine Fisheries Service, Grant \#NA09NMF4520285.

[24] Pettis, H.M., Pace, R.M. III, Schick, R.S. and P.K. Hamilton. 2018. North Atlantic Right Whale Consortium annual report card. Amended Report to the North Atlantic Right Whale Consortium, October 2017. www.narwc.org

[25] Pettis, H.M., Pace, R.M. III, and P.K. Hamilton. 2018. North Atlantic Right Whale Consortium annual report card 2018. Report to the North Atlantic Right Whale Consortium, November 2018. www.narwc.org

[26] Sharp, S.M., McLellan, W.A., Rotstein, D.S., Costidis, A.M., Barco, S.G., Durham, K., Pitchford, T.D., Jackson, K.A., Daoust, P.Y., Wimmer, T., Couture, E.L., Bourque, L., 
Frasier, T., Frasier, B., Fauquier, D., Rowles, T.K., Hamilton, P.K., Pettis, H., and Moore, M.J. 2019. Gross and histopathologic diagnoses from North Atlantic right whale Eubalaena glacialis mortalities between 2003 and 2018. Diseases of Aquatic Organisms. doi: $10.3354 /$ dao03376

[27] van der Hoop, J. M., Corkeron, P., Kenney, J., Landry, S., Morin, D., Smith, J. and M.J. Moore. 2016. Drag from fishing gear entangling North Atlantic right whales. Marine Mammal Science. 32, 619-642. doi: 10.1111/mms.12292

[28] Waring, G.T., Josephson, E., Maze-Foley, K., and P.E. Rosel (eds.). 2016. US Atlantic and Gulf of Mexico Marine Mammal Stock Assessments - 2015. NOAA Technical Memorandum NMFS-NE-238. 


\section{Appendix}

Ropeless Consortium Meeting Agenda

November $6^{\text {th }}, 2018$

New Bedford Whaling Museum, New Bedford, MA

\begin{tabular}{|c|c|}
\hline Presentation title & Speaker \\
\hline Welcome and scientific update & Michael Moore, Woods Hole Oceanographic Institution \\
\hline $\begin{array}{l}\text { Update from the Atlantic Large Whale Take Reduction } \\
\text { Team }\end{array}$ & Scott Kraus, New England Aquarium \\
\hline \multicolumn{2}{|l|}{ Ropeless gear retrieval and marking systems } \\
\hline Ropeless acoustic trap/pot marking systems & $\begin{array}{l}\text { Mark Baumgartner, Woods Hole Oceanographic } \\
\text { Institution }\end{array}$ \\
\hline $\begin{array}{l}\text { An 'endless season' of ropeless fishing trials, Desert Star } \\
\text { Systems }\end{array}$ & Marco Flagg, Desert Star Systems LLC \\
\hline $\begin{array}{l}\text { Development and testing of line free fishing gear to } \\
\text { reduce entanglement of North Atlantic right whales }\end{array}$ & Richard Riels, SMELTS \\
\hline EdgeTech Ropeless Fishing System & Rob Morris, EdgeTech \\
\hline $\begin{array}{l}\text { Fiobuoy F Series, a ropeless buoy solution to marine } \\
\text { entanglements }\end{array}$ & John Fiotakis, Fiomarine \\
\hline Ashored Innovations & Maxwell Poole, Ashored Innovations \\
\hline On-call buoy, bottom-stowed line spool & Keenan Ball, Woods Hole Oceanographic Institution \\
\hline \multicolumn{2}{|l|}{ Experimental gear testing and feedback } \\
\hline MLA and IFAW working hard to preserve right whales & Dave Casoni, MLA and C.T. Harry, IFAW \\
\hline Southern Gulf of St. Lawrence snow crab fleet & Robert Hache, ACA \\
\hline $\begin{array}{l}\text { Initial ropeless gear trials in the California Dungeness } \\
\text { crab fishery }\end{array}$ & Geoff Shester, Oceana \\
\hline $\begin{array}{l}\text { NOAA Fisheries' Northeast Fisheries Science Center } \\
\text { gear research }\end{array}$ & Henry Milliken, NOAA Fisheries \\
\hline \multicolumn{2}{|l|}{ Experimental fisheries and regulatory and policy change } \\
\hline Ropeless experimentation and the regulatory landscape & Michael Asaro, NOAA Fisheries \\
\hline $\begin{array}{l}\text { Whale-safe fishing gear to reduce the incidence of } \\
\text { entanglements in North Atlantic right whales }\end{array}$ & Ed Trippel, DFO \\
\hline "Ropeless" fishing, the Massachusetts perspective & Erin Burke, Massachusetts Division of Marine Fisheries \\
\hline \multicolumn{2}{|c|}{ Market interests: Building a whale-safe advantage and investment opportunities } \\
\hline The MSC and North Atlantic right whales & Marin Hawk, MSC \\
\hline Seafood market connections & Michelle Cho, New England Aquarium \\
\hline Ropeless fishing investor interest & Stephan Reckie and Nick Lukianov, Angelus Funding \\
\hline \multicolumn{2}{|l|}{ Wrap-up } \\
\hline Ropeless Consortium board election & Heather Pettis, New England Aquarium \\
\hline Ropeless Consortium summary and board election & Michael Moore, Woods Hole Oceanographic Institution \\
\hline
\end{tabular}

